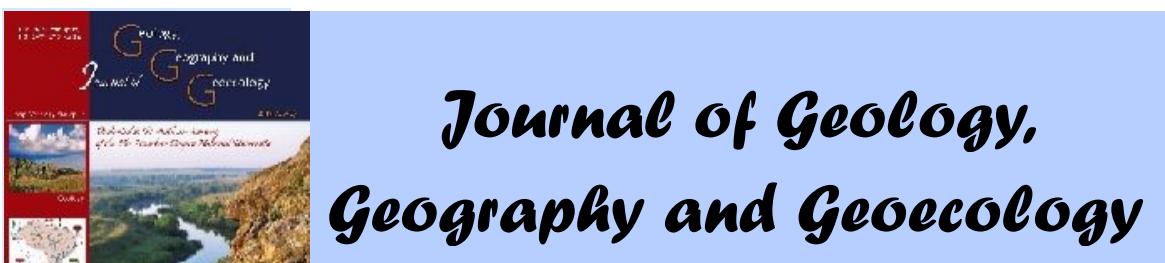

Journal home page: geology-dnu-dp.ua

Journ.Geol.Geograph. Geoecology, 27(2), 285-293 doi: $10.15421 / 111852$

Kuzyshyn A.V., Poplavska I.V.

Journ.Geol.Geograph.Geoecology, 27(2), 285-293

\title{
Analysis of Territorial Differences of the Social Sphere elements in the Areas of the Carpa- thian-Podillia Region
}

\author{
Kuzyshyn A.V., Poplavska I.V.
}

Ternopil Volodymyr Hnatiuk National Pedagogical University, Ternopil, Ukraine, e-mail: kuzyshyn_a@ukr.net, innapoplavska@ukr.net

Received 17.07.2018;

Received in revised form04.09.2018;

Accepted 19.09.2018

\begin{abstract}
The article is devoted to the problem of the social sphere functioning of the areas in the Carpathian-Podillia region, in particular the emphasis is placed on the differentiation of the levels of its individual components, the dynamics of their changes and the complex analysis of functionality. The state of this sphere directly influences the economy and culture of the country and the region, and therefore the sectors of education, health
\end{abstract} care, culture, housing and communal services, etc. play a significant role in the economic development of the territory. Territorial boundaries of the research are defined within Transcarpathian, Lviv, Ivano-Frankivsk, Chernivtsi, Vinnytsia, Khmelnytskyi and Ternopil regions, among which there are established economic, labor-resource and informational-communicative connections, which also should be considered as the strong side of such cooperation. Several basic components of the social sphere (education, culture, medicine, housing and communal services, trade and mass catering, communication) were selected for studying the differentiation of the social sphere elements of the areas of the Carpathian-Podillia region, for each several criteria were chosen (in general over 20). All suggested criteria represent a qualitative component of functioning: in education. They are the amount of preschool institutions for children, the number of pupils / listeners / students per number of inhabitants. Medical sphere includes the providing the population with doctors, middle medical personnel, hospital beds, planned capacity of outpatient clinics. The sphere of culture deals with the provision of population with cultural institutions and their attendance. The housing and communal services sector embraces the level of equipped apartments and indicator of residential space. Retail and catering services cover the indicators of trade turnover for main groups of goods and providing a decent number of trade areas, the field of communication includes access to communication facilities for different variants of their activity. This allowed analysing the level of formation and functionality of the social sphere individual components of the region in general and in its individual areas. On this basis, the ranking of the areas of the CarpathianPodillia region was carried out in terms of the social infrastructure elements formation. In addition, a comparative analysis of the social sphere development level to the indicators of the Western Ukrainian region and Ukrainian is provided. Official statistics from the State Statistics Service of Ukraine, as well as regional statistical offices, were used for the survey.

Key words: Carpathian-Podillia region, geospatial organization, social sphere, education, culture, medicine, housing and communal services, trade and mass catering, communication, matrix of functioning level

\section{н ліз територі льних відмінностей елементів соці льної сфери обл стей рп тсько- одільського регіону}

узишин . ., опл вськ . .

ернопільський н ціон льний пед гогічний університет імені олодимир $\quad$ н тюк, ернопіль, кр їн, kиzуshyn_a@ukr.net,innapoplavska@ukr.net

нот ція. т ття присвячен проблемі функціонув ння соці льної сфери обл стей рп тсько- одільського регіону, зокрем 3 кцентов но ув гу н диференці ції рівнів окремих ії компонентів, дин міці їх зміни т комплексному н лізу функціон льності. т н д ної сфери безпосередньо вплив є н економіку й культуру кр їни т регіону, тому сектори освіти, охорони здоров'я, культури, житлово-комун льного господ рств тощо відігр є зн чну роль в господ рському розвитку території. ериторі льні межі дослідження визн чені в меж х к рп тської, ьвівської, в но- р нківської, ернівецької, інницької, мельницької т ернопільської обл стей, між якими скл лися уст лені господ рські, пр цересурсні т інформ ційно-комунік тивні зв'язки, які т кож в рто вв ж ти сильною стороною т кої співпр ці. ля дослідження диференці ції елементів соці льної сфери обл стей рп тсько- одільського регіону було обр но кільк б зових скл дових соці льної сфери (освіт , культур , медицин, житлово-комун льне господ рство, торгівля і м сове х рчув ння, зв'язок), для кожної з яких було обр но кільк критеріїв (з г лом їх пон д 20). е дозволило про н лізув ти рівень сформов ності $\mathrm{T}$ функціон льності окремих скл дових соці льної сфери регіону з г лом т в окремих його обл стях. цій основі було 
проведено р нжув ння обл стей рп тсько- одільського регіону з рівнем сформов ності елементів соці льної інфр структури. ож под но порівняльний н ліз рівня розвитку соці льної сфери до пок зників хідноукр їнського регіону т пересічноукр їнських. ля проведення дослідження було використ ні офіційні ст тистичні д ні ерж вної служби ст тистики кр їни, т кож обл сних упр влінь ст тистики.

лючові слов : pп тсько- одільський регіон, геопроторов орг ніз ція, соці льн сфер , освіт , культур , медицин , житлово-комун льне господ рство, торгівля ім сове х рчув ння, зв'язок, м триця рівня функціонув ння.

Introduction. The modern stage of Ukrainian society development is oriented on social values that in the current environment reflects growing social weight of the creation of socially necessary product. The state of this sphere directly affects the economy and culture of the country; on this basis, one could claim that people engaged in education, health care, culture, housing and communal services etc. play a significant role in the economy. The example of the leading countries of the world shows that in addition to much attention to material production, a lot of effort are applied to priority social development, the prerequisites for social orientation of the economy are formed, to carry out state policy in the name of human as the main generator of civilization progress.

The problem of the development and functioning of the constituent elements of the social sphere is the research area of a large number of national and foreign scientists. V.I. Kutsenko and Y.V. Ostafiichuk consider the social sphere as a sphere of human activity, the result of which are services that meet the needs of society as well as individual members and are associated with the creation of added value (Kutsenko, Ostafiichuk, 2005). N.G. Pigul points out that the organizational mechanism for building a social sphere should be based on clearly defined functions, principles and tasks that will allow more effective implementation of the state social policy in order to improve the quality of life of the population (Pigul, 2013). Y. Oliinyk and A. Stepanenko consider the study of the social space of territorial communities and their social locality as an important direction in the study of social geography (Oliinyk, Stepanenko, 2012). L.M. Niemec considers the social sphere from the point of view of the spatial-temporal organization of society in terms of globalization influences; innovation-investment image of territories, model development and social-geographic zoning for optimization of the society territorial organization and ensuring optimal living conditions of the population, participation in the regions development of strategies (Niemec, 2003). We have also partially considered this problem when evaluating the employment of the Carpathian-Podillia region in the social sphere (Kuzyshyn, 2015a; Kuzyshyn, 2015b;Kuzyshyn, 2018).

With the increasing significance of the social sphere functioning, there is a need for a detailed analysis of the level of its components formation and the achievement of the complexity in providing the relevant services. The relevant issues seem to have the need to determine the current state of formation and demand of individual elements of the social sphere, as well as the level of their provision in a specific region, which allows determining its rating position in the region. To do this, we need to analyse a system of indicators that will allow us to form a comprehensive view of the social sphere of the Carpathian-Podillia region.

Purpose, task and methods of research. In preparation of this study, it was planned to determine, based on the analysing statistical information, the level of formation and functionality of the social sphere of the research region. For this purpose, statistical information was used over the period from the 90's of the twentieth century to 2016. This allowed to determine the trends of the functioning of the social sphere and its components.

To conduct research, we have selected a system of indicators, which served the criteria for evaluating certain elements of the social sphere educational sphere (the coverage of children by preschool institutions; the number of students of comprehensive educational institutions per 10 thousand people; the number of students of vocational schools per 10 thousand people; the number of students of higher educational institutions with I-IV levels of accreditation per 10 thousand people), cultural sphere (availability of library funds per 100 people; availability of club membership per 100 people; attendance of museum institutions per 100 people; 8 - attendance of theatres per 100 people; 9 - attendance of concert events per 100 people), sphere of health care (availability of doctors per 10 thousand people; availability of average medical personnel per 10 thousand people;availability of hospital beds per 10 thousand people; planned capacity of outpatient clinics per 10 thousand people), housing and communal services (availability of housing space; an indicator of the level of private houses), trade and mass catering (availability of trade areas, retail turnover of enterprises per person (thousand UAH), retail sale of alcoholic beverages per person (1)), connection (number of subscribers of mobile communication; number of cable connection subscribers; the share of households having access to the Internet. It should be emphasized that they allow to evaluate the functionality of certain elements not from the point of view of quantity, but quality - provision, 
availability, demand of a certain social sphere element, which, in our opinion, reflect the real state of formation of the social sphere and makes it possible to differentiate its components according to the level of functionality formation.

In the process of research, the method of clusterisation was used. On the basis of the qualitative indicators analysis characterizing the social sphere of the areas of the Carpathian-Podillia region, a hierarchical cluster analysis was carried out with the subsequent construction of the dendrogram (using the Euclidean distance at clusterization).

Presentation of the main material. Territorial boundaries of the research are defined within Transcarpathian, Lviv, Ivano-Frankivsk, Chernivtsi, Vinnytsia, Khmelnytskyi and Ternopil regions (the area covers $19.1 \%$ of the territory of Ukraine and is home to $23.5 \%$ of the country's population). These areas have a compact location, which positively affects their cooperation and high interdependence. Sufficiently well-established business, labour, information and communication should also be considered as the strong side of such cooperation. However, historically, these territories were formed not as one, because in different historical periods they were part of various state institutions. To a certain extent, such territorial attachment also affected the ethnic composition of the population in the mentioned areas, which can be defined as diverse.

Consideration of social sphere elements should be carried out in the sectorial version of the assessment, but taking into consideration a certain territorial level.

The level of social sphere development is determined by the demand for services, and those, in their turn, vary according to the real possibilities of society at one or another stage of development. In today's conditions of an unstable economic situation in the country, the demand for many types of services has decreased due to low profits of the population, although there is an increase in interest in certain types of services (information, advertising, including tourism, health care, etc.).

The social sphere has certain territorial differences in the level of development and structure. Significantly higher level of its development and a wider sectorial structure is in cities compared to rural areas, in more economically developed industrial regions than in less developed agricultural areas.

The educational sphere is an important element in the formation of the social environment, the formation of an enlightened society and is a prerequisite for the preservation of intellectual society. Important indicators that characterize this area of the social sphere are qualitative characteristics of the educational space of the study area, for example, the coverage of children by preschool institutions, the number of students in general education institutions per 10 thousand people, the number of students of vocational schools, the number of higher education institutions students of I-IV accreditation levels per 10 thousand people. Such indicators allow us to assess the state of the educational environment in the research area. During 1995-2016, in the areas of the Carpathian-Podillia region, the rate of coverage of children in preschool institutions increased (from 31 preschoolers / 100 children of the corresponding age in 1995 to 62 preschoolers / 100 children of the corresponding age in 2016), which even exceeded the average Ukrainian index starting from 2010 (Statistical Collection «Regions of Ukraine», 2017. Part 1).Higher level of security is characteristic of the Podilsk regions. From 1995/1996 academic year up to 2013/2014 the number of students of comprehensive educational institutions in the amount of 10 thousand people decreased (from 1464 to 1039 students per 10 thousand population) and only during 2016/2017 academic year there was a tendency for an increase in the number of students in accordance to the number of residents (1067 students per 10 thousand population). It should be noted that this indicator has more positive numbers than the average in Ukraine. Over the period of 2000-2016 there was a decrease in the number of students of vocational education institutions per 10 thousand people from 104 to 81 students (but it is worth mentioning that these indicators are more positive than in Ukraine in general). The highest indicator is characteristic of the Lviv region (in 2016 - 107 students of vocational schools per 10 thousand people). As to the indicator of the number of higher educational institutions students in the Carpathian-Podillia region there was an increase in the number of students per 10 thousand people from 2000/2001 academic year to 2005/2006 academic year, but in subsequent academic years their number decreased faster than in Ukraine in general (Statistical Collection «Regions of Ukraine», 2017. Part 1).

When evaluating the educational sphere according to the criteria chosen by us, the matrix table confirms that the most developed this sphere is in the Lviv region, and the indicators of the educational environment functioning in the Vinnytsia, Ternopil and Chernivtsi regions are also high, while in other areas of the region there are problems with the separate components of the estimation of availability development of the educational sphere, or generally low efficiency of their functioning (Table 1). Compared with the average Ukrainian indicators and indicators characteristic to all areas of the Western Ukrainian region. In this territory there 
were always higher indicators of coverage of children by preschool institutions, the highest number of pupils and students in general education and vocational schools. Only a reduction in the number of students in higher educa-tion institutions in the region is higher than in Ukraine in general (this can be justified by the outflow of students to European, first and foremost, Polish educational institutions).

Culture covers institutions and establishments that produce cultural goods, offer spiritual values to the population etc. (libraries, theatres, clubs, museums, film studios, television, radio, newspaper and magazine publishing houses). Their placement is also associated with the peculiarities of people's resettlement: there is the higher concentration of cultural objects in large populations settlements. In the areas of the Carpathian-Podillia region there are over 5,7 thousand libraries, 6,4 thousand club facilities and cultural buildings (Statistical Collection «Regions of Ukraine», 2017. Part 1).They are placed according to the administrative division (in settlements - centres of administrative-territorial units, in urban microdistricts) and on a production principle - on the basis of enterprises, educational institutions, etc. For our analysis, we selected two areas - the availability of these institutions, which were evaluated through the index of availability of certain institutions for population and the population attendance of cultural and art establishments.

The indicator of the availability of cultural institutions, in particular library funds and club facilities in the Carpathian-Podillia region, is higher than the average in Ukraine and in the Western Ukrainian region in general. Although since 2000 these figures are decreasing in Ukraine, the decline rate in the region under study is not so significant. Thus, the average indicator of the availability of library funds in the region comprises 688 copies per 100 people, and in most regions (Vinnytsia, Lviv, Ternopil, Khmelnytskyi) it exceeds 700 . If on average in Ukraine the provision of places in clubs is 10 places per 100 people, in this region it exceeds 15 (in Ternopil and Khmelnytskyi regions - 18).

Among the museum establishments of the Carpathian-Podillia region (161 establishments, almost $28 \%$ of the total Ukrainian indicator) dominate regional history, historical, memorial museums. Most of them are situated in regional centres (the leader is Lviv), and among the regions as a whole the leader is Ternopil region -30 . The rate of attendance of museums in the regions of the area is higher (in 2016 - 46 visits per 100 people) than in Ukraine in general (37 visits per 100 people) and continues to grow. Higher indicators from the average regional rate were recorded in Transcarpathian and Lviv regions (48 and 75 visits per 100 inhabi- tants), the lowest - in Chernivtsi (31 visits per 100 inhabitants) (Statistical Yearbook of Ukraine for 2016, 2017. Kyiv, 2017). The reason for such a significant ampli-tude can be both quantitative indicators of museums as well as the practical interest of tourists and recre-ationists to this form of rest.

The largest number of professional theatres is in the Lviv region ( 9 out of 112, which operate in Ukraine). There are 27 professional theatres in the region in general. Regarding attendance, despite the established stereotype that the population of western Ukraine are theatre fans, the indicators are lower than in Ukraine - 11 visits per 100 inhabitants (with the exception of the Lviv region - 18 visits per 100 inhabitants) (Statistical Yearbook of Ukraine for 2016, 2017. Kyiv, 2017). It should be noted that this indicator includes a significant tourist component, because many Ukrainian and foreign tourists consider it mandatory to visit theatres during their travel programs.

Assessing the level of functioning of the cultural sphere components, it should be noted that their highest level is characteristic of the Lviv and Khmelnytskyi regions, high and relatively balanced - in Vinnytsia and Ternopil regions. If we analyse the dynamics of individual indicators, then from 2000 to 2016 in the areas of the Carpathian-Podillia region there is a deterioration and lagging behind the average Ukrainian indicator and indicator of the Western Ukrainian region in general regarding the availability of library funds, but there is an increase in the availability of places in clubs, there is an interest in visiting museums and the attendance of theatrical at concert events decreases.

The health-improving complex includes a system of medical and recreational institutions that provide health care (disease prevention, treatment), health improvement and recreation. There are 50000 doctors of all specialties in the healthcare institutions within the region (almost $27 \%$ of the total Ukrainian indicator) and more than 100 thousand of medical staff (more than $27 \%$ of the total Ukrainian indicator). The availability of doctors in the region under study is one of the highest in the country, but the percentage of sick people is constantly increasing due to unfavourable living conditions, inappropriate nutrition, and so on. Thus, from 2000 to 2016, the availability of doctors per 10 people in the Carpathian-Podillia region ranges from 45 to 50 specialists (in Ukraine this figure is significantly lower). The indicator of the availability of average medical personnel is also at the high level (more than 100 per 1 thousand population) as well as the amount of hospital beds (more than 77 per 10 thousand population). The highest rates are characteristic for Ivano-Frankivsk, Lviv and Ternopil regions. 
The situation with the planned capacity of outpatient clinics is quite tense (all medical institutions conducting an outpatient appointment - outpatient clinics, out-patient departments, clinics, outpatient departments of hospitals, medical health centres, etc.). The situation improves since 2010, but lags behind the all-Ukrainian indicators. Only in two regions of the area (Vinnytsia and Transcarpathian) the planned capacity of outpatient clinics is higher than the average in Ukraine.

The medical field, according to selected criteria, has the highest index of availability of doctors, average medical personnel in the IvanoFrankivsk, Lviv and Ternopil regions. Quite qualitative medicine can function in the Khmelnytskyi region. In other regions, the rating positions of the medical sector are rather low and, accordingly, indicate the problem of its development.

Housing and communal services satisfy the needs of people in housing, provide functioning of dwelling houses, hotels, small enterprises and institutions. This direction of the social sphere provides maintenance and repair of the housing stock and communal infrastructure. The entire housing fund in the Carpathian-Podillia region comprises 256 million square meters, which is more than $26 \%$ of the state's housing stock. The city housing stock has a higher level of gas, hot and cold water supply, and sewerage than in the rural areas. Within the studied region, the main residential areas are concentrated in rural areas (more than $55 \%$ of the total regional index). Today, in order to improve the living conditions of the population, considerable attention is paid to the development of investment (at the expense of private costs of individuals and legal entities) and individual housing construction. The average availability of housing stock in the region is higher $\left(25.8 \mathrm{~m}^{2} /\right.$ person) than in Ukraine in general $\left(22.9 \mathrm{~m}^{2} /\right.$ person). Among the areas of the region, the highest level of housing availability is characteristic of Vinnytsia (almost $30 \mathrm{~m}^{2} /$ person) and Khmelnytskyi region $\left(27 \mathrm{~m}^{2} /\right.$ person), the lowest is in the Lviv region $\left(23 \mathrm{~m}^{2} /\right.$ person).

Communal infrastructure is an integral part of residential and household needs of the population and enterprises. It covers electricity, heat supply, gas supply, water supply, sewage, improvement and sanitary cleaning of the territory. Among indicators that characterize the arrangement of apartments in the Carpathian-Podillia region, the indicators of natural gas supply, sewage and centralized water supply are the highest. According to the index of natural gas supply, the highest indicator is characteristic of Ternopil, Chernivtsi and Khmelnytskyi regions (in all, over $93 \%$ of the total regional indicator). The best water supply is typical for Lviv and Ternopil regions, sewage services and hot water supply - for the same areas. Centralized heating is best arranged in Ternopil and Khmelnytskyi regions.

With a consolidated assessment of the indicators that ensure the quality of the housing and communal complex functioning of these territories, the ranking of the highest positions are typical for the Ternopil and Khmelnytskyi regions, while Lviv, Ivano-Frankivsk and Vinnytsia regions are close to the average.

Trade and catering include retailers and mass caterers.

The most comfortable conditions for trade according to the trade space are noticeable in Lviv and Ivano-Frankivsk regions, high enough in Ternopil, Khmelnytskyi and Transcarpathian regions.

In the total volume of commodity circulation, groceries make up $65 \%$, non-food products $-35 \%$. The highest indicators of retail turnover per person is in Lviv region (13,5 thousand UAH / person, the indicator exceeds the average Ukrainian), and the lowest - in Ternopil region (7,6 thousand UAH / person). In addition to the traditional enterprises of the industry, a network of specialized stores, fast food catering establishments develope. An interesting indicator is the consumption of alcoholic beverages (in the calculation of pure alcohol 1 liter per person, this criterion is an applicator of the social structure level in the regions), according $t$ which the minimum indices are characteristic for predominantly Podilsk regions (Vinnytsia and Ternopil within 1.31 / person), and the maximum - for the Lviv region $-2,71 /$ person.

According to the indicators characterizing the trade sector and mass catering, it can be noted that there is a very small amplitude between the regions, which allows us to assert the practically same level of functioning of the trading sphere.

Communication as a branch of economy consists of enterprises, lines and nodes, which provide the process of transmitting information over a distance (ie, telecommunication). This includes communication departments, telephone and telegraph stations, post office, radio broadcasting, television, etc.

From the beginning of the XXI century along with the media (radio and television), an individual connection is developing extremely fast. At the same time, its traditional form - phone connection - is improving, interlacing with other types (satellite, radio). Another group of the latest telecommunication facilities widely uses video equipment and computers. This is telefax, e-mail, Skype, etc.

Due to accessibility to new forms and types of communication, there is a significant difference in the background of the regions. For example, Lviv region is the leader. Transcarpathian and Vin- 
nytsia regions have rather high index characteristics as well. If one is to estimate the region's share of the indicator of the mobile subscribers number or the number of cable television subscribers, it is slightly more than $10 \%$, which corresponds to the correlation index of the population share in the Ukrainian index.

On the basis of the conducted component analysis, it is possible to rank the regions of the Carpathian-Podillia region in terms of the functioning of the elements of the social sphere. The method of clusterisation analysis was used to conduct the research, which allowed to analyse the state of functioning and differentiation of the level of social sphere elements in the context of the mentioned administrative units.

For the characteristics of each social sphere element of the region there is a corresponding rank (from 1 to 7), according to the indicator occupied by the region (the rank is higher, provided that it has the higher corresponding absolute index). Fewer points provide a better ranking.

Several blocks of criteria were used during the formation of matrix. They were grouped into: educational sphere: 1 - the coverage of children by preschool institutions; 2 - number of students of comprehensive educational institutions per 10 thousand people; 3 - the number of students of vocational schools per 10 thousand people; 4 - the number of students of higher educational institutions with I-IV levels of accreditation per 10 thousand people; cultural sphere: 5 - availability of library funds per 100 people; 6 - availability of club membership per 100 people; 7- attendance of museum institutions per 100 people; 8 - attendance of theatres per 100 people; 9 - attendance of concert events per 100 people; sphere of health care: $10-$ availability of doctors per 10 thousand people; 11 availability of average medical personnel per 10 thousand people; 12 - availability of hospital beds per 10 thousand people; 13 - planned capacity of outpatient clinics per 10 thousand people; housing and communal services: 14 - availability of housing space; 15 - an indicator of the level of private houses; trade and mass catering: 16 - availability of trade areas, 17 - retail turnover of enterprises per person (thousand UAH); 18 - retail of alcoholic beverages per person (1); connection: 19 - number of subscribers of mobile communication; 20 number of cable connection subscribers; 21 - the share of households having access to the Internet.

Table 1.RankingofpartsofCarpathian-Podilliaregionaccording to the level of social sphere elements formation, indexes of $2016^{*}$

\begin{tabular}{|c|c|c|c|c|c|c|c|c|c|c|c|c|c|c|c|c|c|c|c|c|c|c|c|}
\hline \multirow{3}{*}{ Regions } & \multicolumn{23}{|c|}{ Criteria for evaluation / rank } \\
\hline & \multicolumn{4}{|c|}{$\begin{array}{l}\text { Educa-tional } \\
\text { sphere }\end{array}$} & \multicolumn{5}{|c|}{ Cultural sphere } & \multicolumn{4}{|c|}{ Medical sphere } & \multicolumn{2}{|c|}{$\begin{array}{l}\text { Housing } \\
\text { and com- } \\
\text { munal } \\
\text { services }\end{array}$} & \multicolumn{3}{|c|}{$\begin{array}{c}\text { Trade and } \\
\text { mass catering }\end{array}$} & \multicolumn{3}{|c|}{$\begin{array}{l}\text { Communi- } \\
\text { cation }\end{array}$} & \multicolumn{2}{|c|}{$\begin{array}{l}\text { Combined } \\
\text { ranking of } \\
\text { the region }\end{array}$} \\
\hline & 1 & 2 & 3 & 4 & 5 & 6 & 7 & 8 & 9 & 10 & 11 & 12 & 13 & 14 & 15 & 16 & 17 & 18 & 19 & 20 & 21 & total & rank \\
\hline Vinnytsia & 1 & 7 & 2 & 4 & 1 & 2 & 3 & 6 & 5 & 6 & 6 & 6 & 2 & 1 & 5 & 7 & 6 & 1 & 2 & 1 & 6 & 80 & 4 \\
\hline Transcarpathian & 4 & 1 & 6 & 7 & 7 & 6 & 2 & 4 & 2 & 7 & 7 & 7 & 1 & 6 & 4 & 5 & 2 & 3 & 3 & 3 & 1 & 88 & 6 \\
\hline Ivano-Frankivsk & 6 & 2 & 5 & 5 & 5 & 4 & 5 & 4 & 7 & 1 & 1 & 4 & 6 & 3 & 3 & 2 & 5 & 2 & 2 & 6 & 4 & 82 & 5 \\
\hline Lviv & 5 & 4 & 1 & 1 & 4 & 5 & 1 & 1 & 1 & 3 & 3 & 1 & 5 & 7 & 2 & 1 & 1 & 6 & 1 & 2 & 3 & 58 & 1 \\
\hline Ternopil & 3 & 5 & 3 & 2 & 3 & 3 & 3 & 3 & 6 & 4 & 2 & 2 & 4 & 4 & 1 & 3 & 7 & 2 & 6 & 4 & 5 & 75 & 2 \\
\hline Khmelnytskyi & 1 & 6 & 4 & 6 & 2 & 1 & 4 & 3 & 3 & 5 & 4 & 3 & 3 & 2 & 3 & 4 & 4 & 4 & 5 & 5 & 7 & 79 & 3 \\
\hline Chernivtsi & 2 & 3 & 5 & 3 & 6 & 4 & 6 & 5 & 4 & 2 & 5 & 5 & 7 & 5 & 6 & 6 & 3 & 5 & 4 & 7 & 2 & 95 & 7 \\
\hline
\end{tabular}

"Calculated forStatistical Collection «Regions of Ukraine», 2017. Part 1; Statistical Collection «Regions of Ukraine», 2017. Part 2; Statistical Yearbook of Ukraine for 2016, 2017.

As a result of the analysis, the method of clusterization was used through multivariate statistical analysis. On the basis of indicators generalization of blocks-criteria, an algorithm for assessing the functioning of the social sphere of the areas of the Carpathian-Podillia region was formed:

1) the initial mass of information was analysed according to the indicators, which can be considered as two sub-masses - indicatorsstimulators and indicators-destimulators;

2) for each of the six groups of indicators, the actual ranking is performed on the basis of absolute indicators, which are given in Statistical Collection «Regions of Ukraine», 2017. Part 1; Statistical Collection «Regions of Ukraine», 2017. Part 2; Statistical Yearbook of Ukraine for 2016, 2017;
3) for each region, a certain amount of rating indicators is determined, which demonstrate its own quantitative assessment of the social functionality in the regions according to the factors of stimulation;

4) in the format of a graph-tree, one can demonstrate the distribution of regional areas according to the level of social sphere formation and functionality;

5) the suggested meaning assessment of the final regions grouping according to the indicators of the functioning of the social sphere.

This methodological approach to qualitative rating indicators allows us to form a cohe-rent picture of the problem and to evaluate the social sphere functioning of the areas of the re-gion under 
study. It shows satisfactory results provided that there is a significant amount of evidence in the output masses of information (in our case more than 20 indicators) and their statistical homogeneity and equilibrium.

On the basis of the analysis, one can see (Fig. 1) that the most balanced social sphere functions in Lviv region. This is due to the balanced organization of the educational sphere at the level of preschool, general and higher education, the cultural sphere, which is monitored due to the demand of cultural institutions and their updating, the sphere of trade and mass catering that ensure the availability of food products and services for the local population and tourists, as well as communication (using of new and existing forms of communication by population) - these indicators provided the leading position of the region.

The general picture of the assessment shows that the majority of regions (Vinnytsia, Transcarpathian, Ivano-Frankivsk, Ternopil, Khmelnytskyi) have similar indicators of social development, but each of them often has its own advantages in the development of the social sphere elements. This does not allow to assert a balanced functioning level of the social sphere within these territories. Thus, for Vinnytsia region, there is the domination of education, culture, housing and communal services and communications in the social sphere, but the low level of functioning of the medical staff sector and trade. Transcarpathian region is characterized by formation and demand of the sphere of communication and trade, and other areas of social sphere are rather problematic. Ivano-Frankivsk region has a sufficient level of functioning of medical services, housing and communal services and trade. Ternopil region shows balanced functioning of the components of the educational sphere, culture, medicine, housing and communal services. Khmelnytskyi region is marked by formation and functioning of the sphere of culture, medicine, housing and communal services. As for the Chernivtsi region, in comparison with other regions of the Carpathian-Podillia region, this region has only high level in the sphere of education, while in the other groups of indicators there are unbalanced and low indicators. The suggested clustering of the regions of the research area (Figure 1) shows their place according to the balance indicators of the social sphere functioning.

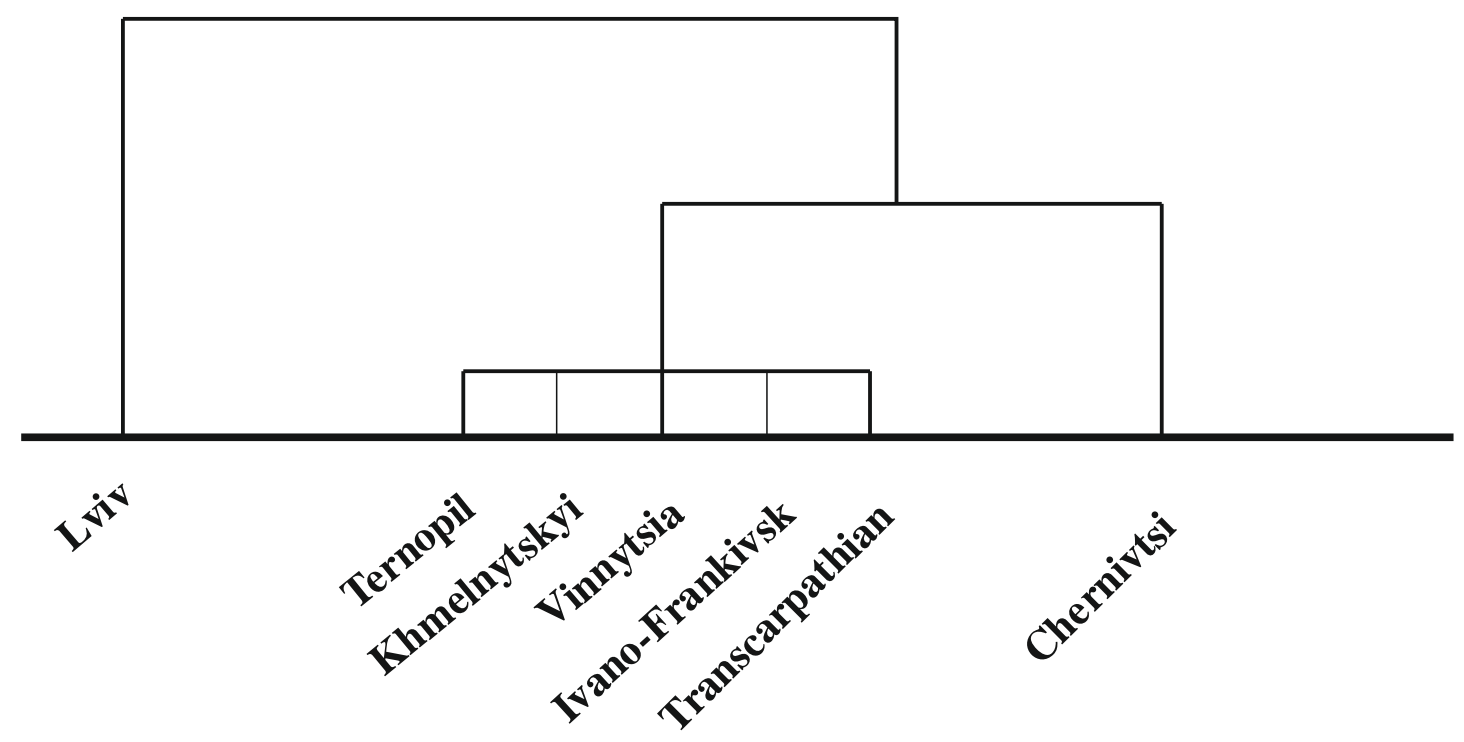

Fig. 1. Clusterization of the areas of the Carpathian-Podillia region according to balance indicators of the social sphere components

Conclusions. The social sphere of Ukraine in general and its major regions are experiencing the period of diversification of its components. With significant potential, the regions of Ukraine do not always use their potential properly.

In the process of consideration of each social sphere component of the Carpathian-Podillia region, we analysed the main groups of criteria. This al-lowed determining the differentiation of levels of social sphere formation of the region in general. On the background of the regional indicator of the social sphere functioning and formation Lviv region is marked by a high level of education, culture, trade and mass catering, as well as communications - these indicators provided the leading positions of the region. For most areas of the region (Vinnytsia, Transcarpathian, Ivano-Frankivsk, Ternopil, Khmelnytskyi) there is a very narrow amplitude of total indicators, which can be a confirmation that in the consolidated form the social sphere does not have a significant difference in these areas. The weakness of the social sphere of Chernivtsi region according to the criteria we have chosen is based on 
the low positions of the cultural sphere, housing and communal services as well as medical sphere.

\section{References}

Kutsenko, V.I., 2008. Sotsial'na sfera: real'nist' i kontury maybutn'oho (pytannya teoriyi i praktyky) [Social sphere: reality and contours of the future (questions of theory and practice)]. AspektPoligraf Publishing Ltd., Nizhyn(in Ukrainian).

Kutsenko, V.I, Ostafiychuk Y.V., 2005. Transformatsiyi sotsial'noyi sfery Ukrayiny: rehional'nyy aspekt [Transformation of the social sphere of Ukraine: the regional aspect. Orion, Kyiv (inUkrainian).

Kuzyshyn, .V., 2015. Kharakterystyka sotsial'noyi sfery zakhidnoukrayins'kykh oblastey $\mathrm{v}$ svitli zaynyatosti naselennya. [Characteristics of the social sphere of the western Ukrainian regions in the light of employment of the population]Lviv social-geographical school: history, theory, Ukrainian studies studios: Materials of the AllUkrainian conference with the participation of foreign scientists devoted to the 70th anniversary of the Department of Economic and Social Geography of the Ivan Franko National University of Lviv (Lviv, November 19-20, 2015). Lviv Ivan Franko National University, Lviv. 378-384 (in Ukrainian).

Kuzyshyn, ., 2018. Heoprostorova dyferentsiatsiya elementiv sotsial'noyi sfery oblastey Karpat s'koPodil's'koho rehionu [Geospatial differentiation of the social sphere elements of the CarpathianPodillia region]. The Scientific Issues of Ternopil Volodymyr Hnatiuk National Pedagogical Uni- versity. Series: Geography. 44(1). 64-71 (in Ukrainian).

Kuzyshyn, A., 2015. Function of social sphere of the Carpathian-Podillia region through the assessment of employment Service industries in the Carpathia-Podilla Region. Probltmatyka 31 Międzynarodowej Konferencii Naukowej nt. «Miedzynarodowt uwarunkowania rozwojo przemysłu i usług». Warszawa - Krakow. 69.

Niemec, L.N., 2003. Ustojchivoe razvitie: social'nogeograficheskie aspekty (na primere Ukrainy) [Sustainable development: socio-geographical aspects (on the example of Ukraine)]. Fakt, Kharkiv(in In Russian).

Oliinyk,Y.B., Stepanenko, A.V., 2012. Sotsial'nyy lokalitet zhyttya osobystostey i terytorial'nykh spil'nostey [Social locality of the life of individuals and territorial communities]. Economic and Social Geography (65) 2 (65), 3-22 (in Ukrainian).

Pigul, N.G., 2013. Osnovy funktsionuvannya sotsial'noyi sfery [Fundamentals of the social sphere functioning]. Scientific Bulletin of the Poltava University of Economics and Trade. 56(1), 4650(in Ukrainian).

Statystychnyy zbirnyk «Rehiony Ukrayiny», 2017 [Statistical Collection «Regions of Ukraine», 2017]. Part 1. Kyiv(in Ukrainian).

Statystychnyy zbirnyk «Rehiony Ukrayiny», 2017 [Statistical Collection «Regions of Ukraine», 2017.] Part 2.Kyiv (in Ukrainian).

Statystychnyy shchorichnyk Ukrayiny za 2016 rik, 2017[Statistical Yearbook of Ukraine for 2016], Kyiv(in Ukrainian). 